\title{
CONTRIBUTIONS OF GEOPHYSICAL TECHNIQUES TO THE EXPLORATION OF THE MOLNÁR JÁNOS CAVE (BUDAPEST, HUNGARY)
}

\section{PRISPEVEK GEOFIZIKALNIH METOD PRI RAZISKAVAH JAME MOLNÁR JÁNOS (BUDIMPEŠTA, MADŽARSKA)}

\author{
Gergely SURÁNYI ${ }^{1 *}$, Endre DOMBRÁDI ${ }^{2,3} \&$ Szabolcs LEÉL-ÖSSY ${ }^{4}$
}

\begin{abstract}
UDC 556.34 (439)

Gergely Surányi, Endre Dombrádi \& Szabolcs Leél-Össy: Contributions of geophysical techniques to the exploration of the Molnár János Cave (Budapest, Hungary)

Located in the centre of the Pannonian basin, one of the hottest basins in Europe with high average heat flow values, Hungary has long been famous for hot water springs and frequent cave occurrences. The Molnár János Cave, an active thermokarstic cave, belonging to the Buda Hills karst system, lies beneath a highly populated district of Budapest. Its large passages are almost completely filled by lukewarm water. Only the upper part of its largest known chamber rises above the water level, which offers an excellent site to examine recent cave generation processes. However, hitherto, no dry subsurface gateway existed towards this chamber; it was only accessible underwater. In this paper, we present the results of various geophysical investigations including GPR, magnetic and seismic methods, carried out in a close cooperation between geophysicists and speleologists. The aim of the measurements was to determine the precise position of the hall relative to a nearby drift. Based upon the successful seismic survey and first break analysis, a precise and efficient boring could be designed to realise the connection. Finally, a passage between the two cavities has been established and, thus, the chamber of the cave is now accessible to the whole scientific community.

Keywords: Molnár János Cave, active hydrothermal cave, seismic tomography.
\end{abstract}

\author{
Izvleček UDK 556.34 (439) \\ Gergely Surányi, Endre Dombrádi \& Szabolcs Leél-Össy: \\ Prispevek geofizikalnih metod pri raziskavah jame Molnár \\ János (Budimpešta, Madžarska)
}

Madžarska leži v centralnem delu Panonskega bazena, območja $\mathrm{z}$ visokim geotermalnim tokom in $\mathrm{z}$ njim povezanimi termalnimi vrelci in jamami. je aktivna termalna kraška jama hribovju Buda in leži neposredno pod gosto naseljenim območjem Budimpešte. Velike rove skoraj v celoti zaliva termalna voda, nad nivojem podtalnice je le zgornji del največje dvorane v jami, ki predstavlja izjemno mesto za študijo aktivnih speleogenetskih procesov v termalnih jamah. Naraven dostop do dvorane je možen samo preko popolno zalitih rovov. V prispevku predstavimo niz geofizikalnih in speleoloških raziskav, ki smo jih izvajali $\mathrm{z}$ namenom določitve položaja dvorane glede na bližnji umetni tunel. Predvsem dobri rezultati seizmičnih meritev so omogočili uspešno načrtovanje in izvedbo novega rova, ki sedaj povezuje umetni jarek in dvorano.

Ključne besede: Jama Molnár János, aktivna hidrotermalna jama, seizmična tomografija.

\footnotetext{
${ }^{1}$ Research Group of Geology, Geophysics and Space Research Sciences, Hungarian Academy of Sciences, Pázmány Péter sétány 1/C, 1117 Budapest, Hungary, email: surda@pangea.elte.hu

${ }^{2}$ Department of Geophysics and Space Sciences, Institute of Geography and Earth Sciences, Eötvös Loránd University, Pázmány Péter sétány 1/C, 1117 Budapest, Hungary

${ }^{3}$ Netherlands Research Centre for Integrated Solid Earth Science (ISES), VU University, De Boelelaan 1085, 1081 HV Amsterdam, The Netherlands, email: dombradi@elte.hu

${ }^{4}$ Department of Physical and Applied Geology, Institute of Geography and Earth Sciences, Eötvös Loránd University, Pázmány Péter sétány 1/C, 1117 Budapest, Hungary, email: losz@geobio.elte.hu
}

Received/Prejeto: 16.02 .1010 


\section{GEOLOGICAL OVERVIEW OF THE RÓZSADOMB CAVE SYSTEM}

It was more than a hundred years ago that quarrying activities led to the encounter of the first hydrothermal caves in the surroundings of the Rózsadomb, Budapest (Fig. 1). During the last century about 50-60 caves and 50 cave indications were discovered here. In the Rózsadomb the age of the oldest known rock is Upper Triassic (Schafarzik \& Vendl 1929; Horusitzky 1935; Wein 1977). In the studied area two Triassic formations occur, the Födolomit Formation, a massive dolomite body and the Mátyáshegyi Formation consisting of limestone and dolomite (Haas et al. 1993). These formations are followed by a hiatus of over $150 \mathrm{My}$ and covered by Paleogene and Quaternary formations. The most important among the young formations is the several tens of meters thick Szépvölgyi Limestone Formation of Upper Eocene age (Dudich 1959). The caves found in the Rózsadomb area were developed mainly in this type of rock. In this area, the Szépvölgyi Limestone is usually overlain by the Buda Marl (Upper Eocene-Lower Oligocene). It has vari-

able but always considerable clay content and is thus not readily karstifiable. Nevertheless, several cave corridors and the Molnár János Cave itself are located in this layer (Leél-Őssy \& Surányi 2003).

Tectonic activity played an utmost important role in the genesis of the Rózsadomb caves. During the Oligocene-Early Miocene, based on NW-SE-oriented compression and NE-SW extensions, tectonic effects caused an ENE-WSW-trending shear zone. In this zone the second-order Riedel shears (E-W directed dextral faults) and the NW-SE tension fractures opened the way for descending meteoric water and for ascending thermal water, thus allowing for corrosion and the formation of cave galleries. It is well reflected in the orientations of the main cave corridors, which generally follow the secondorder Riedel faults in an 'en-echelon' geometry. Between the Middle Miocene and Quaternary, new N-S to NESW-trending normal faults were formed by ESE-WNW extension. The Pleistocene tectonics did not overprint the original en-echelon ge-

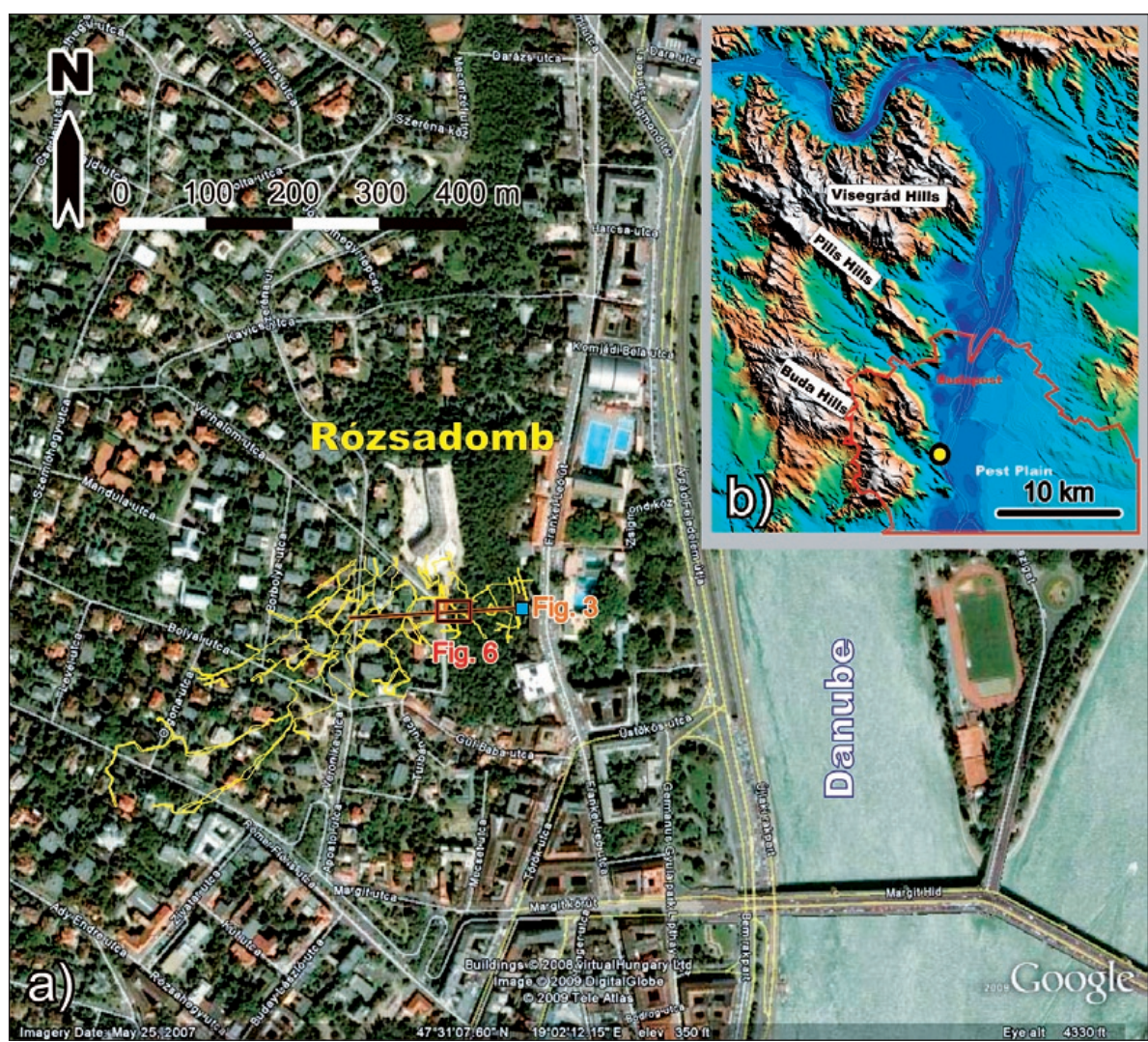

Fig. 1: a) Planar view of the corridors of the Molnár János Cave (yellow solid lines - courtesy Kalinovits et al.) overlain on the satellite image of the Rózsadomb area, Budapest (Google Earth). The entrance of the cave and the Malom pond are marked by the cyan square. Location of Figs. 3 \& 6 is also indicated. $b$ ) The inset map shows the high resolution digital elevation model of the Buda Hills and its surroundings. The yellow circle highlights the location of the Molnár János Cave (Fig. 1a). ometry of the galleries but reactivated and dilated the faults. N-S-oriented neotectonic faults can also be observed in several caves. Finally, the temporally and spatially varying rate and amount of Quaternary uplift of the area have altered the orientations of the cave galleries located in different tectonic blocks. As a summary, these caves have provided good opportunity to investigate the different episodes of tectonic development in the Buda Hills (Fodor et al. 1991 1994; Benkovics \& Dudko 1993).

Apart from a few paleokarstic forms, which belong to Triassic, Cretaceous to Eocene and Oligocene phases of karstification and lack evidence of any thermal effects (Nádor 1991), the majority of the Rózsadomb caves are characterised by much younger ages. Uranium series dating performed on samples from the Józsefhe- 
gyi Cave yielded ages around 500 ky for the paleokarstic halls and $200 \mathrm{ky}$ for the rocks constituting the main passage in the cave. On the basis of these measurements, the other members of the Rózsadomb Cave system are also considered to be around this age interval (Leél-Össy \& Surányi 2003).

\section{A YOUNG MEMBER OF THE BUDA THERMOKARST SYSTEM: THE MOLNÁR JÁNOS CAVE}

The Molnár János Cave underneath an exclusive district of Budapest (Rózsadomb - Fig. 1) is considered to be the sole active living cave in the Buda cave system (Leél-Össy \& Surányi 2003). It is a fairly unique situation that the corridors of the cave inhabit the subsurface of a highly urbanized area that is the capital of Hungary. The major maximum depth, and the length of the known sections totalling $5.5 \mathrm{~km}$. The mouth of the cave is located close to the river Danube (ca. $200 \mathrm{~m}$ ). Since the water table inside the cave exceeds the level of the Danube (ca. $95 \mathrm{~m}$ asl at Budapest) by only a few metres, the deepest sections of the cave are at sea level. The continuously evolving active cave is the deepest and youngest member of the Buda thermokarst system. part of the cave system is under water, reaching $100 \mathrm{~m}$

are hardly found; the known barite and calcite sites are independent from the cave generation and predate it.

This cave, similarly to the other caves in its surroundings, is of thermalkarstic origin that is generated by hot springs (Bakalowicz et al. 1987; Klimchouk et al. 2000). The ascendant thermal waters only have a trifling capacity for dissolution of limestone. It does not provide a sufficient explanation for the origin of the large horizontal cave systems in the Rózsadomb. Therefore, the theory of mixture corrosion (Bögli 1965; Runnels 1969; Plummer 1975) is widely accepted. According to this concept, the combined solutions, with different temperatures and ion compositions, have enough capacity to dissolve the limestone. In the case of the Rózsadomb, roughly $20 \%$ of the precipitation in the Buda and Pilis Hills infiltrates into the deepest karst zones, warms up, and begins an eastward flow in the karstwater in a quasi static or very slow manner. When it reaches the covered karst of the Pest Plain (Figs. 1 \& 2), overlain by impermeable layers, the pressure increase triggers a westward ascent of the water along the fault zone at the right bank of the Danube and finally reaches the surface. The circulation time along the different tracks ranges from a few to a maximum of 30000 years. Near the surface, mixing occurs among the as-

Fig. 2: Sketch of the Buda Thermal Spring system illustrating the mixing of ascending and descending waters (Leél-Össy \& Surányi 2003).

The temperature of the water in its known passages varies between 17 and $27^{\circ} \mathrm{C}$ (Adamkó et al. 1992). The upper sections are enclosed by the upper Eocene Buda Marl Fm., which is characterised by variable but considerable carbonate content (Takácsné Bolner \& Kraus 1989). In contrast with the large caves in the Buda Hills, the corridors of the Molnár János Cave are still in a corrosive stage (Ford 1995). Recent mineral precipitations cending waters of different temperature and ion composition and the subsurface cold karstwater, which is characterized by the mean annual surface temperature of the area (Rudnicki 1989). Therefore, persistent mixture corrosion is provided. An additional condition for the occurrence of mixture corrosion was the denudation of the impermeable Kiscell Clay, which originally covered the karstic rocks. According to Nádor and Sásdi (1995), 


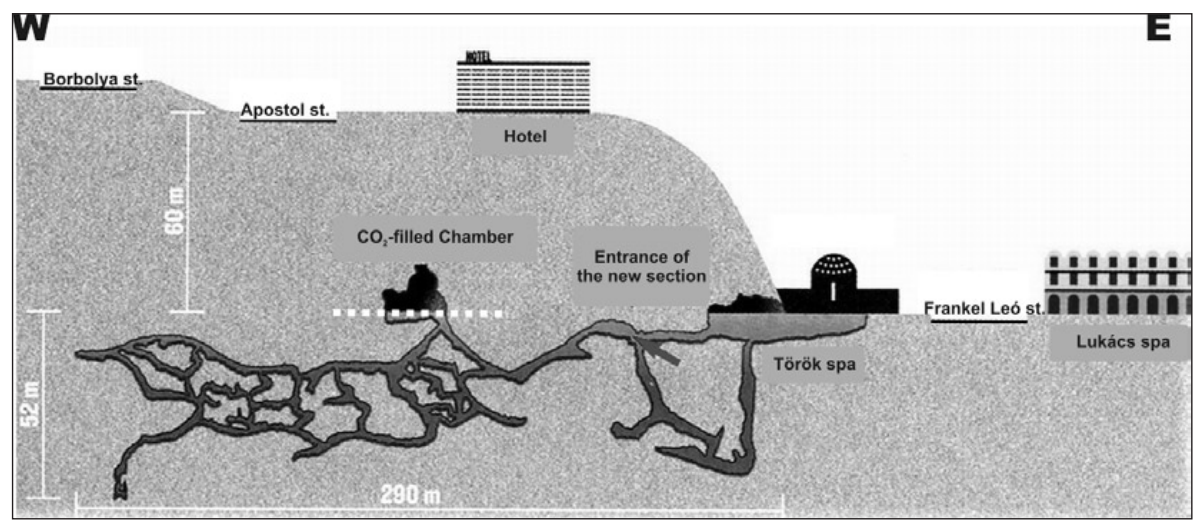

Fig. 3: Cartoon illustrating the passages and the location of the Molnár János Cave in vertical cross section. The image was compiled according to the state of exploration until 2007. Since then both the length and depth of the known corridors have substantially increased. The position of the drift is out of plane but indicated in the vicinity of the $\mathrm{CO}_{2}$-filled Chamber by the dashed white line. generation of several caves at the karstwater level. The differential uplift of the hills (e.g. Szanyi et al. 2009) and consequent drop of the base level strongly controlled the zone of mixture corrosion and generated multi-level caves.

The large caves in the Rózsadomb area (Harcsaszájú, Pál-völgyi, Szemlöhegyi, Ferenc-hegyi, Mátyáshegyi and József-hegyi Cave, in the order of the year of discovery), which are above the actual karstwater level at it took place during the Upper Miocene; thus, the caves of the Rózsadomb must be much younger.

As described above, the Buda Hills are characterised by strong tectonic activity over various geological periods, offering good conditions for the circulation of the waters. The different moving waters have been able to flow in the tectonic fractures and in the diaclases (Fodor et al. 1991), and consequently, the walls of the cracks and fractures are continuously dissolved, leading to the present, are now considered as paleokarsts without active water circulation (Ford \& Williams 2007). The mineral precipitation in these caves commenced 10-100 ka ago. Conversely, the Molnár János Cave is found at and below the karstwater level; thus, the mineral precipitation is expected to take place at a later stage. It offers an excellent opportunity to study solution processes both below and above the karstwater.

\section{EXPLORATION HISTORY OF THE MOLNÁR JÁNOS CAVE}

The cave was named after János Molnár, a pharmacist, who first suggested the existence of a cave that belongs to the same water system as the nearby Malom pond (Mill pond - Figs. $1 \& 3$ ). The pond was backed up in the $13^{\text {th }}$ century to supply the water mills in the area. János Molnár investigated the spring head and sampled the karstwater. His analyses proved the similarity in chemical composition between the karstwater and Malom pond. Therefore, he suggested that the water flows into the pond through an undiscovered passage. Later, advances in scuba diving techniques enabled the exploration of the hidden cavity. Unfortunately, the former spring head was severely clogged; thus, the first few attempts in the 1950s failed. A rapid propagation commenced in the 1970s, when divers could enter in the outer corridors of the cave and a $500 \mathrm{~m}$ long, new section of the cave was discovered in a relatively short time (Fig. 4).

In 1977, a team led by Hubert Kessler drove a 180 $\mathrm{m}$ long westward directed drift close to the entrance of the cave. The drift was perpendicular to the street and the cliff face and was designed as a shortcut to ease the transportation of the guests between the hotel and the spa (Fig. 3). The elevation of the drift was $3 \mathrm{~m}$ higher than the karstwater level; thus, several air-filled cham-

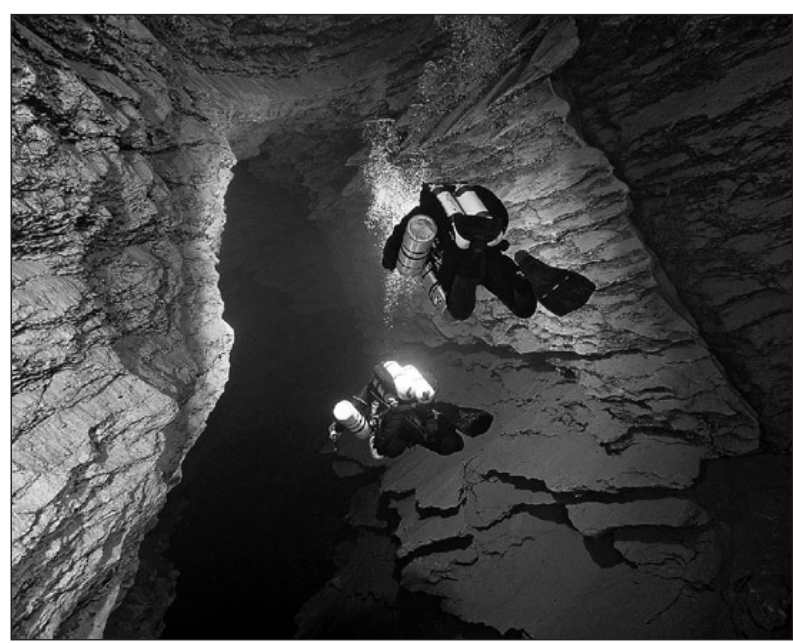

Fig. 4: Underwater photo of one of the passages (Photo: $R$. Husek). 
bers were expected to be intersected by the drilling. Our presented results reveal that the drift was indeed very close to the largest chamber. Three decades passed until the next breakthrough in 2002, when the endpoint of the old section was opened and new passages were discovered again. These corridors often reached 5-6 $\mathrm{m}$ in width and $20 \mathrm{~m}$ height, and thus were relatively easy to swim through. The largest chamber, entitled ' $\mathrm{CO}_{2}$-filled Chamber, was found in the same year. The upper part of the $70 \mathrm{~m}$ long and $15-25 \mathrm{~m}$ wide chamber, almost $1000 \mathrm{~m}^{3}$ in volume, rises well above the water. According to the chemical analysis, the air contains $6.5 \% \mathrm{CO}_{2}$. As a result, it is improper for inhalation and hindered the investigation of new air-filled holes. The obvious solution to assist the further exploration and enable the detailed study of ongoing cave generation was to create a new dry-footed entrance and aerate the $\mathrm{CO}_{2}$-filled Chamber. From a technical point of view, such a passage is also very useful as the $120 \mathrm{~m}$ shorter route saves gas for the divers, makes rescue easier in emergency and allows the faster, safer and more cost-efficient exploration of the subsequent sections.

\section{CAVE DETECTION WITH GEOPHYSICAL TOOLS}

In general, the term 'cavity detection' refers to the situation when the position of the void in question is unknown. Various near-surface geophysical techniques have been successfully used for such purposes in recent years. In our case, the objective of the research was slightly different from the classical cavity detection problem, because the chamber in the cave was already discovered and studied by the amateur cave researchers. Furthermore, the chamber was not investigated from the surface but from a drift inside the hill cradling the nearby underwater cave system. Nevertheless, to make a connection between the man-made drift and the natural cavern was similar to the task of finding a void beneath the surface as it is in geotechnical and engineering applications.

During the past decades, a great number of surface geophysical methods have proved to be capable of locating subsurface cavities either on natural karstic terrains (e.g. Ballard et al. 1983) or in industrial areas (e.g. Piwakowski et al. 1997). The advance of the acquisition and processing techniques enabled a more complex interpretation of the anomalies related to presumed cavities and allowed the estimation of their extent and geometry in 3D (Beres et al. 2001). However, the choice of the appropriate method providing both sufficient penetration and resolution at the same time, always depends on the circumstances of the given problem (Grandjean \& Leparoux 2004).

GPR measurements are widely used for shallow targets in low conductivity regions (e.g. Mellett 1995). The buried objects can be mapped in detail with high precision even in urban areas, where other geophysical tools might fail due to various sources of noise. Microgravity surveys can image the subsurface cavities based on the density contrast between the air- or water-filled void and the rock matrix (Butler 1984). They are characterised by a relatively larger depth of investigation. However, a good geological control is often required for successful and plausible interpretation. If the shallow subsurface is not too heterogeneous in terms of electrical properties, resistivity profiling can also be employed to delineate cavities with good resolution (e.g. Gautam et al. 2000). Here, the cavities in question are contoured in the profiles as anomalously high or low resistivity regions. The potential of seismic methods to find underground voids has also been investigated by several authors. These include both the traditional P-wave reflection seismic (e.g. Grandjean et al. 2002) and the surface-wave diffraction techniques (e.g. Leparoux et al. 2000). Several case studies have been published, which demonstrate the benefits of high-resolution seismic surveys in cavity detection (Gochioco, 1990; Miller \& Steeples, 1991; Piwakowski et al. 1997; Grandjean \& Leparoux, 2004).

In summary, it can be noted that the most precise delineation of the near-surface heterogeneities, particularly the boundaries of buried voids, can be obtained through the integration of the results of several complementary approaches (Beres et al. 2001).

To create a passage between the cave and the already existing drift, we had to use complementary geophysical tools to assist the direct boring technique. The limitations and benefits of each method, with respect to the cavity research aspects, were taken into consideration. In the following section, we describe how the most effective geophysical measurement was selected to find the smallest distance between the voids. 


\section{GPR AND MAGNETIC MEASUREMENTS}

The first attempt to connect the chamber with the drift was a test drilling. The direction of the planned drill hole relied on a preliminary and rather imprecise subaqueous mapping. After 6 metres advance without hitting the target, the drilling could not be continued further into the rock body. Therefore, we decided to test various geophysical methods to select the most appropriate measurement to constrain the location of the chamber.

GPR measurements are often used in cavity detection due to their simplicity and effectiveness (Benson 1995; Owen 1995). Although the penetration was expected to be strongly reduced by the marl body (Buda Marl Fm.), it was considered to be acceptable and particularly easy for testing. Beyond the rapid attenuation of the radar signals, the major problem was that most of the energy was diffracted by the fissures and air-gaps between the side wall of the tunnel and the rock itself. Therefore, the penetration of the radar signals was not sufficient, and the GPR profiles did not show any firm indication of a larger cavity, which could have improved the determination of a new drill hole.

Joint effort made by scuba divers and geophysicists was of key importance to accomplish a successful measurement. With the assistance of amateur divers, we decided to carry out a simple magnetic survey. The idea of taking a strong permanent magnetic source into the hall and detecting the related magnetic anomaly along a pro- file in the tunnel was promising. The peak of the anomaly could have corresponded to the smallest distance between the magnetic source and the magnetometer. Prior to the measurements in the cave, we tested the proposition on the surface using an Overhauser magnetometer. The permanent magnet was assembled by smaller pieces. The whole stack yielded a detectable, 10-15 nT signal in $12 \mathrm{~m}$ distance parallel with its longer axis. Since the absolute precision of the Overhauser magnetometer is ca. $0.2 \mathrm{nT}$ (Turner et al. 2007) and the presumed thickness of the rocks between the voids was no greater than 10 $\mathrm{m}$, measuring the field of our magnetic source through the rocks seemed feasible. Unfortunately, the magnetic survey also failed due to highly variable magnetic noise inside the drift. After switching on the equipment, a rapidly changing field with 300-400 $\mathrm{nT}$ amplitude was measured. This level of noise overprinted the signal of the permanent magnet; thus, it was unrecognisable. The exact source of the abnormal level of noise remained unclear. One possible explanation can be related to the small metal hooks regularly spaced on the side wall of the tunnel. The measurement was done ca. $80 \mathrm{~m}$ from the entrance of the tunnel and $50 \mathrm{~m}$ below the surface. The external magnetic noise, most probably generated by the tram and car traffic in the street, might have been effectively conveyed into the tunnel by these hooks.

\section{SEISMIC SURVEY USING DIRECT WAVE PROPAGATION}

After the failure of the GPR and magnetic survey tests, which could have given a quick and in situ result, we could not avoid using a more sophisticated technique. The location of the chamber was eventually determined by a successful seismic survey. In contrast with the classical way of interpreting cavities on reflection seismic sections, represented by diffraction hyperbolae or signal weakening and concealing deeper reflectors (Grandjean \& Leparoux 2004), our attention was focused on the first breaks. The fact that the seismic source could be placed into the studied cavern enabled the novel concept of using direct $\mathrm{P}$ waves in this particular form of cavity detection problem.

Prior to the measurements, the following technical questions arose as possible problems to tackle: (i) the discrimination of the first arrivals with high precision (i.e. less than $1 \mathrm{~ms}$ ), (ii) providing an accurate triggering procedure to avoid delays, and (iii) the velocity dis- turbances caused by the inhomogeneity of the rocks. We used a 48 channel Summit ${ }^{\mathrm{TM}}$ (DMT) seismic receiver kit (Fig. 5) and hammer and plate as the seismic source. To improve coupling, the spikes of most geophones were tightly planted into pre-drilled holes in the ground. The geometry of the whole spread is illustrated in Fig. 6.

An initial test was performed to obtain the average velocity of the seismic waves through the rock medium. The shotpoints were positioned in the tunnel at both ends of the spread with $0.5 \mathrm{~m}$ offset. A set of the recorded first breaks is shown in Fig. 7. The velocity calculated from the best fit is $1890 \mathrm{~m} / \mathrm{s}$, which closely corresponds to the known velocity of the Buda Marl Formation (Palotai et al. 2008).

In addition to the velocity, this test gave satisfactory answers to the technical problems addressed. Due to the small distance and the excellent coupling, the maximum of the frequency spectrum was around $1 \mathrm{kHz}$, which is 


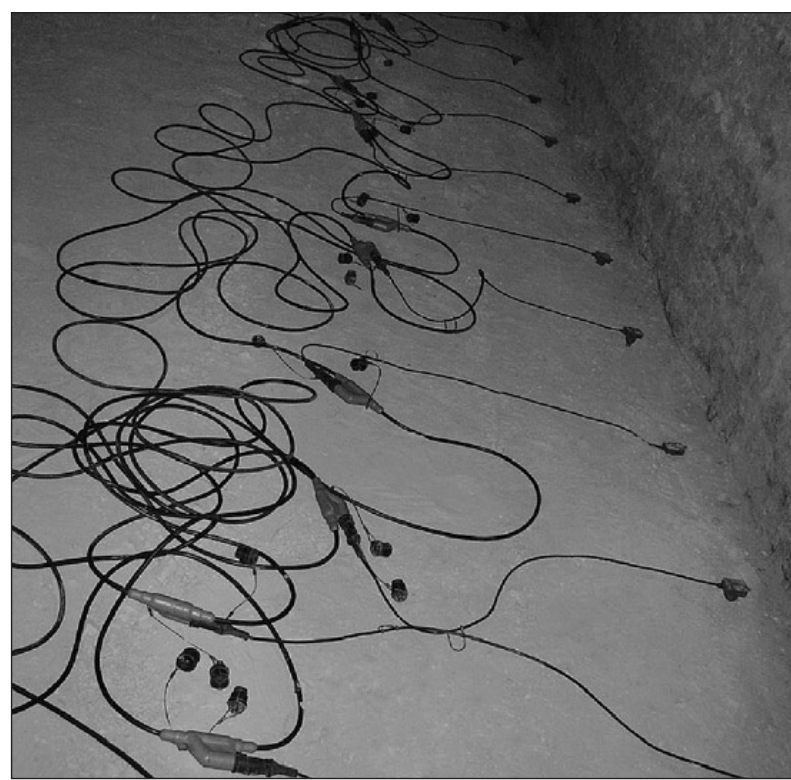

Fig. 5: The geophone spread in the main branch of the drift (Photo: Á. Domján).

considered to be exceptionally high frequency in the practice of land seismics. Consequently, the high frequency enabled precise determination of the first arrivals

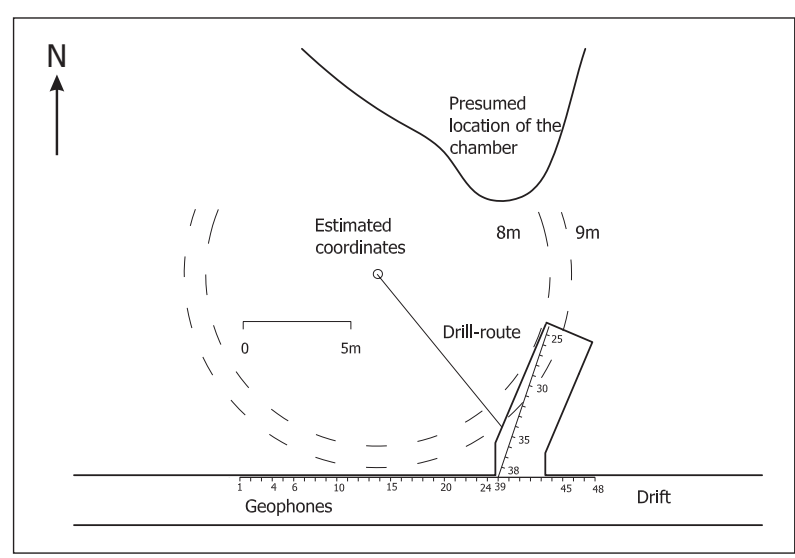

Fig. 6: Sketch of the drift and the chamber including the geophone spreads in the main (geophones 1-24 and 39-45) and the side branch (geophones 25-38). The difference between the presumed location of the chamber and the estimated coordinates calculated according to the results of the seismic survey is clearly visible. The actual drill route is also indicated.

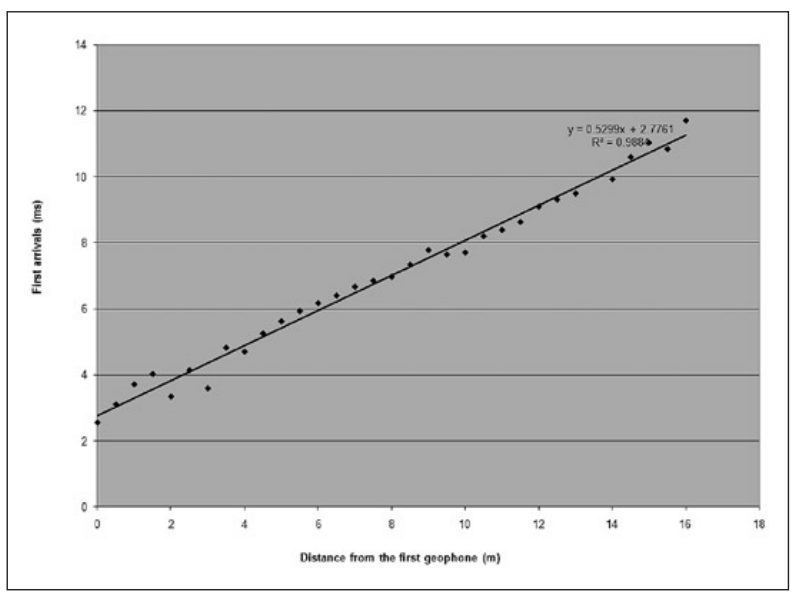

Fig. 7: Velocity estimation for the Buda Marl Fm. The shotpoints were inside the drift and the velocity was calculated from the direct $P$ wave arrivals and the distances of the geophones. The linear regression resulted in a value very close to the known velocity of the formation. The good fit also indicates that the rock body can be considered homogeneous.

even without the aid of any industrial seismic processing software. The scatter of the arrival times plot in Fig. 7 indicates that no significant velocity inhomogeneities occurred on the site. However, given the velocity, the position of the shotpoint calculated from the arrival times deviated from the real shotpoint position. We assumed that the seismic receiver itself accounted for nearly $1 \mathrm{~ms}$ delay due to imprecise trigger timing. Since the desired accuracy of the measurement and, consequently, the precision of the coordinates of the seismic source did not allow a ms-order uncertainty in the timing, we decided to exclude the trigger from our survey set-up. In doing so, we also eliminated the difficulty of submerging and taking the hammer and the sensor into the chamber, which then had to be connected to the trigger unit with several hundred meters of wire. Instead, we controlled the start of the recording manually. The seismic source was provided by a scuba diver inside the chamber, who was hitting the wall with a small hammer at the beginning of each minute. We managed to record two or three out of 8-10 hits of the diver during the predefined $2 \mathrm{~s}$ interval. The recording was repeated six times, resulting in 14 sets of first breaks. 


\section{RESULTS OF THE FIRST BREAK ANALYSIS}

For the sake of precision, the first breaks on the profiles were picked using ProMAX (Landmark) processing software, although their identification was easy even for the naked eye (Fig. 8). Each series was normalized to its average; then, to avoid negative values all series were shifted to $10 \mathrm{~ms}$ zero arrival time. In doing so, the 14 signals hav-

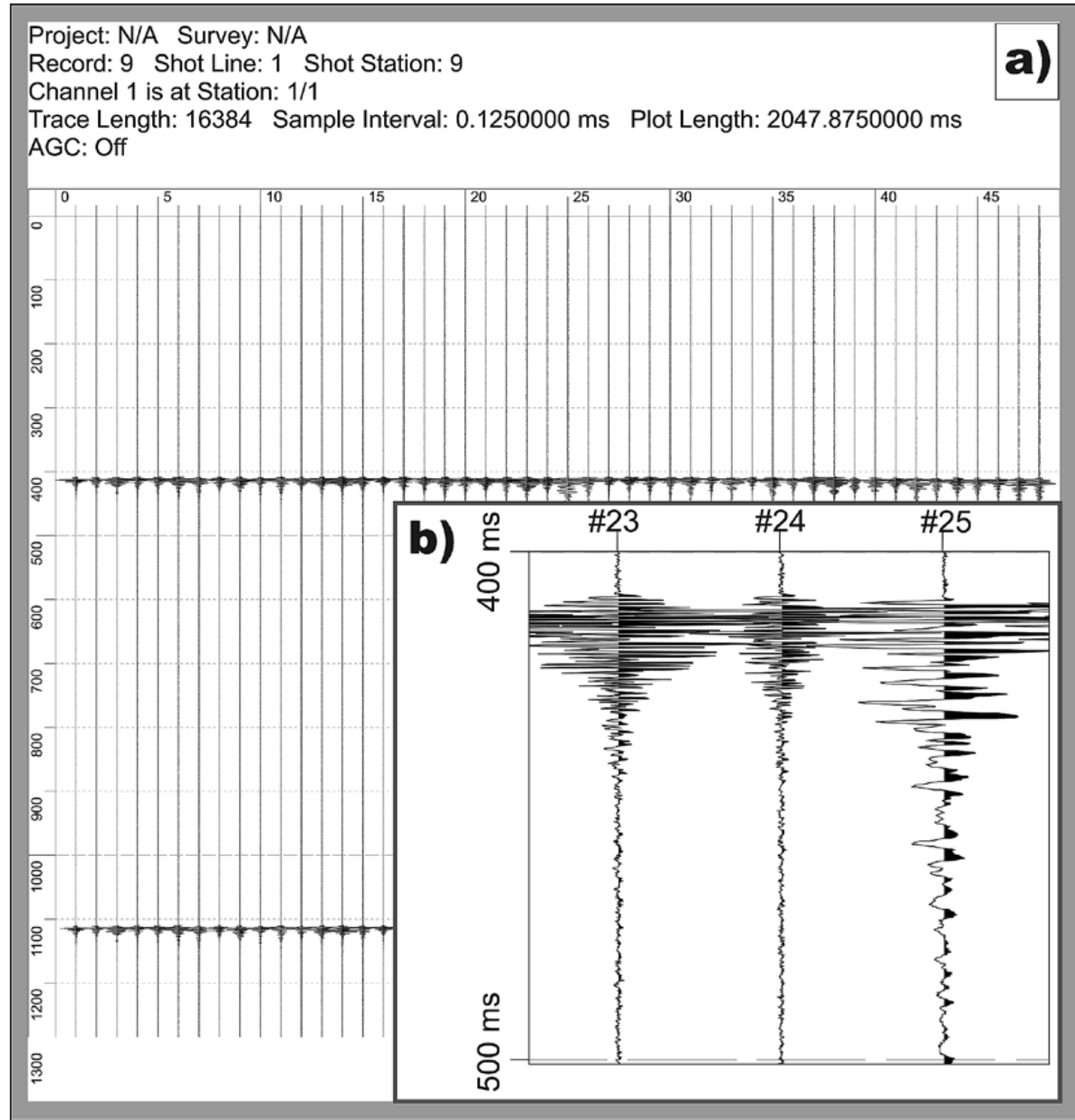

Fig. 8: a) Example of the time sections recording the direct waves from the $\mathrm{CO}_{2}$-filled Chamber. $b$ ) The close-up clearly shows the high frequency of the signals and also highlights the reason for the few bad quality data, which were excluded due to the imperfect coupling. ing arrived at random times could be handled together, and their mean value for each receiver was computed (Fig. 9). A simple quality control was performed on the gathered data. In a few cases, we experienced high values of standard deviation (exceeded $0.05 \mathrm{~ms}$ ) and assumed a bad coupling, and the data were excluded. For instance, the $25^{\text {th }}$ receiver was resting in loose sand, which explains the lower frequency of the recorded signal (see Fig. 8). Finally we could use 44 individual arrival times in total.

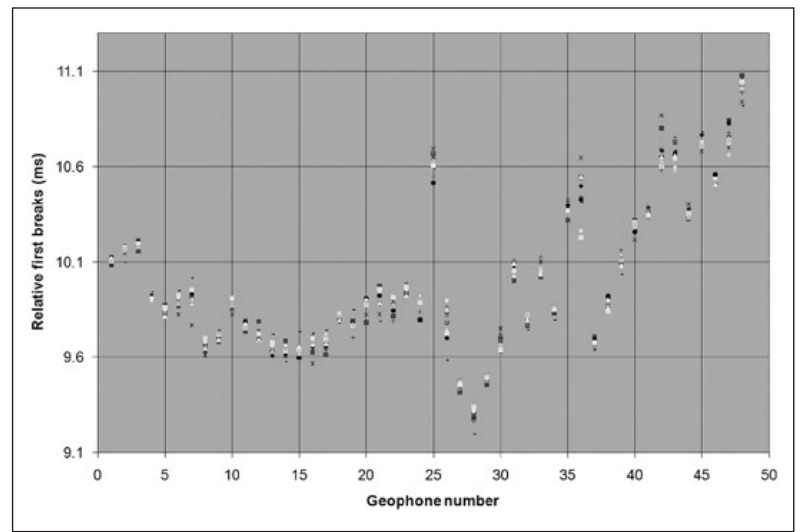

Fig. 9: Relative differences in the first breaks normalised to $10 \mathrm{~ms}$ arrival time. The 14 sets of arrival times are represented by the different symbols. 


\section{INVERSION OF THE DATA: DETERMINATION OF THE COORDINATES OF THE CHAMBER}

To obtain the distance between the shot location and the drift, a simple inversion procedure was applied. The first breaks and the velocity of the propagating seismic wave were the input parameters in the least squares inversion process. The conditional equation was rather simple, formulating the equation of $1 \mathrm{D}$ steady motion:

$$
v=s / t
$$

In this case, $v$ is the velocity of the compressional wave, $s$ is the distance between the chamber and the drift and $t$ is the travel time of the seismic wave.

It was reformulated, using the coordinates of the receivers and the source:

$$
v=\sqrt{\frac{\left(x-x_{0}\right)^{2}+\left(y-y_{0}\right)^{2}+\left(z-z_{0}\right)^{2}}{\left(t-t_{0}\right)^{2}}} .
$$

Here, the coordinates of the seismic source and the geophones are denoted by the letters with and without subscripts, respectively. The output parameters were $x_{0}$ and $y_{0}$, position of the seismic source and $t_{0}$ arrival time. Known parameters were the coordinates of the geophones $(x, y, z)$ and the velocity $(v)$.

The elevation of the geophones above the water level was evaluated by geodetic levelling. The ground of the tunnel, where the geophones were laid out, is $3.6 \mathrm{~m}$ higher than the level of the neighbouring Malom pond. Since the flow within the cave is quite slow, no difference was assumed between the water tables of the chamber and the pond. The elevation of the hammer hits, in other words the $z_{0}$ coordinate of the source, was estimated as $0.2 \mathrm{~m}$ by the scuba diver.

To determine the location of the seismic source, a minimisation process, using the conjugate gradient least squares algorithm, was employed on the equations. During the iteration, we observed that the output coordinates were highly sensitive to the choice of the initial parameters, and the process was often trapped into a local minimum. To avoid unreal scenarios, additional conditional equations were applied, and the results were double checked. From the output coordinates a set of synthetic arrival times was generated, which then was compared with the measured values. Sum of squares and standard deviation of the differences were analysed. The coordinates satisfying the minimum of the above measures were accepted as the final coordinates $\left(x_{0}, y_{0}, z_{0}\right)$ of the source location.

The result of the inversion implied that the shortest way towards the chamber is $8 \mathrm{~m}$ long in the direction perpendicular to the side-branch of the tunnel.

\section{BREAKTHROUGH IN THE 'CO ${ }_{2}$-FILLED CHAMBER'}

Given the results of the inversion process, driving of the connecting passage could be planned. The difference in elevation between the two ends of this drift was $3.4 \mathrm{~m}$; thus, the total length was estimated ca. $9 \mathrm{~m}$. Since tradi-

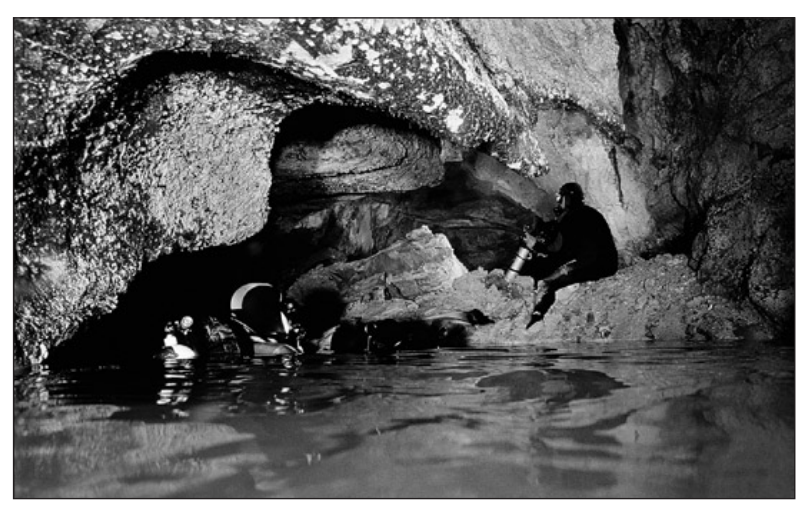

tional mining techniques could not be used, the entire plan relied on the manual work of amateur cave researchers. From this point of view, breaking through a $9 \mathrm{~m}$ thick block of rocks was rather challenging.

Prior to the laborious cutting of the new passage, a control drilling was carried out to test the estimation based on the first break analysis. Due to various practical and technical considerations, the drill route was not in the original direction perpendicular to the axis of the smaller drift. It started at the junction of the drifts with $30^{\circ}$ planar angle and $14^{\circ}$ dip (see Fig. 6). The drill hit the

Fig. 10: The $\mathrm{CO}_{2}$-filled Chamber, now entitled the Hubert Kessler Chamber, revealed from the direction of the drift (Photo: G. Surányi). 
cave after slowly penetrating an $11.5 \mathrm{~m}$ thick rock body. The next control diving confirmed the successful establishment of the connection and reported that the hole hit by the drill was less than $1 \mathrm{~m}$ away from the rock being hammered previously.
The amenable passage was opened up by cutting out the rocks slowly and painstakingly. Hence, the partly air-filled chamber of the Molnár János Cave has been revealed (Fig. 10) and made accessible via not only the subaqueous route. The chamber was named after Hubert Kessler, who established the exploring drift in the 1970s.

\section{CONCLUSIONS}

We presented the geophysical investigation of the Molnár János Cave, an underwater karst system beneath the heart of Budapest. The objective of the research was to create a direct passage between a nearby drift and the only known chamber of the cave, which has an air-pocket. Therefore, the exact direction and distance of the chamber from inside the drift had to be determined. The particular problem was studied in the light of geophysical methods used in classical cavity detection research. The geometry of the two voids was constrained by an unconventional seismic method, placing the source into the cavity in question and utilising the arrival times of the direct waves. Thus, the geometry was calculated from the inversion of the re- corded first breaks and the measured velocity of the rock matrix. This approach gave a precise estimation on the position of the chamber and significantly eased the planning of the boring.

The successful research was a result of fruitful collaboration of geophysicists and speleologists. The discovery has gained a wide publicity and was communicated through various channels of the written and electronic media. A significant step was taken towards the ultimate goal, to bring the thermal karst beneath Budapest, this exclusive natural phenomenon in the heart of a European capital, under the umbrella of the UNESCO protection as being part of the natural world heritage.

\section{ACKNOWLEDGEMENTS}

We thank our reviewers, Petar Milanovic and Tim Bechtel, for their positive remarks and constructive comments. We are grateful for the students of the Eötvös University, the amateur cave researchers and divers, whose assistance was inevitable for the successful research. We acknowledge the financial support received from the Hungarian National Science Fund (OTKA) project NK60445 and the Netherlands Research Centre for Integrated Sol- id Earth Science (ISES). The magnetometers were purchased in the framework of the GVOP-3.2.1 - $2004-04$ $-0390 / 3.0$ project supported by the National Office for Research and Technology (NKTH). The seismic processing software was available by the Landmark University Grant programme. Tamás Tóth is thanked for the fruitful discussions.

\section{REFERENCES}

Adamkó, P., Dénes, Gy. \& Sz. Leél-Őssy, 1992: The caves of Buda.- Council of Budapest, pp. 47, Budapest.

Bakalowicz, M.J., Ford, D.C., Miller, T.E. \& A.N. Palmer, 1987: Thermal genesis of solution caves in the Black Hills, South Dakota.- Bull. Geol. Soc. Am., 99, 729 738 .
Ballard, R.F., Cuenod, Y. \& J.P. Jenni, 1983: Detection of karst cavities by geophysical methods.- Bulletin of the International Association of Engineering Geology, 26-27, 153-157. 
Benkovics, L. \& A. Dudko, 1993: Structural characterization of Rózsadomb.- In: Kleb, B. (ed.) Geological, petrophysical tectonic and paleokarst analyses and evolution. Manuscript, Budapest Technical University, p. 700, Budapest.

Benson, A.K., 1995: Application of ground penetrating radar in assessing some geological hazards: examples of groundwater contamination, faults, cavities.J. Appl. Geophys., 33, 177-193.

Beres, M., Luetscher, M. \& R. Olivier, 2001: Integration of ground-penetrating radar and microgravimetric methods to map shallow caves.- J. Appl. Geophys., 46, 249-262.

Bögli, A., 1965: The role of corrosion by mixed water in cave forming.- In: Stekl, O. (ed.) Problems of the Speleological Research, Czechoslovak. Academy of Science, pp. 125-131, Prague.

Butler, D. K., 1984: Microgravimetric and gravity gradient techniques for the detection of subsurface cavities.- Geophysics, 49, 1084-1096.

Dudich, E., 1959: Paläogeographische und paläobiologische Verhältnisse der Budapester Umgebung im Obereozän und Unteroligozän.- Ann. Univ. Sci. Budapestiensis de Rolando Eötvös nom. Sec. geol., 2, 53-87.

Fodor, L., Leél-Őssy, Sz. \& G. Tari, 1991: En-echelon fractures in a dextral shear zone - Tectonic heritage for a hydrothermal cave (Budapest, Hungary).- Terra Nova, 4, 165-170.

Fodor, L., Magyari, Á., Fogarasi, A. \& K. Palotás, 1994: Tertiary structure evolution and Late Paleogene sedimentation in Buda Mts.- Földtani Közlöny, 124/2, 130-305.

Ford, D.C., 1995: Some thoughts on hydrothermal caves.Cave and Karst Science, 22, 3, 107-118.

Ford, D.C. \& P.W. Williams, 2007: Karst Hydrology and Geomorphology.- Unwin Hyman, pp. 562, Massachusetts.

Gautam, P., Raj Pant, S. \& H. Ando, 2000: Mapping of subsurface karst structure with gamma ray and electrical resistivity profiles: a case study from Pokhara valley, central Nepal.- J. Appl. Geophys., 45, 97-110.

Gochioco, L.M., 1990: Seismic surveys for coal exploration and mine planning.- Lead. Edge, 9, 4, 25-28.

Grandjean, G., Bitri, A. \& G. Sénéchal, 2002: Détection de carrières souterraines par sismique haute résolution à Annet sur Marne (France).- C. R. Acad., Sci. Terre, 334, 441-447.

Grandjean, G. \& D. Leparoux, 2004: The potential of seismic methods for detecting cavities and buried objects: experimentation at a test site.- J. Appl. Geophys., 56, 93-106.
Haas, J. (ed.), 1993: Lithostratic units of Hungary. Triassic.- MÁFI, pp. 278, Budapest.

Horusitzky, H., 1935: Hydrogeology of the right-side bank part of Budapest.- Hidrológiai Közlöny, 18, 1404.

Klimchouk, A., Ford, D.C., Palmer, A.N. \& W. Dreybrodt, 2000: Speleogenesis.- National Speleological Society, Huntsville, Alabama, p. 527.

Leél-Össy, Sz. \& G. Surányi, 2003: Peculiar hydrothermal caves in Budapest, Hungary.- Acta Geologica Hungarica, 46, 407-436.

Leparoux, D., Bitri, A. \& G. Grandjean, 2000: Underground cavities detection using seismic Rayleigh waves.- Eur. J. Env. Eng. Geophys., 5, 33-53.

Mellett, J.S., 1995: Ground penetrating radar applications in engineering, environmental management, and geology.- J. Appl. Geophys., 33, 157-166.

Miller, R.D. \& D.W. Steeples, 1991: Detecting voids in a $0.6-\mathrm{m}$ coal seam, $7 \mathrm{~m}$ deep, using seismic reflection.- Geoexploration, 28, 109-119.

Nádor, A., 1991: Paleokarsts of the Buda Mts.- PhD thesis. Eötvös Loránd University, p. 171.

Nádor, A. \& L. Sásdi, 1995: Paleokarsts and their development of the Buda Mts.- Karszt és Barlang, 1992, pp. 3-10.

Owen, T.E. (ed.), 1995: Ground Penetrating Radar.- J. Appl. Geophys. 33, 1-3, 1-225.

Palotai, M., Bíró, L., Dövényi, P., Hámori, Z., Kádi, Z., Tóth, T. \& G. Surányi, 2008: Geological and geophysical model of the northern part of the Csepel Island and Inner Budapest.- Unpublished research report, Geomega Ltd., p. 27, Budapest (in Hungarian).

Piwakowski, B., Waletet, J.M. \& D. Moreaux, 1997: High resolution seismic prospection of old gypsum mines-evaluation of detection possibilities.- Eur. J. Env. Eng. Geophys., 2, 109-120.

Plummer, L.N., 1975: Mixing of seawater with calcium carbonate groundwater.- Geol. Soc. Am. Mem., 142, 219-236.

Rudnicki, J., 1989: Relation between natural convection and cave formation in hydrothermal karst.- Proceedings $10^{\text {th }}$ International Congress of Speleology, 13-20 August, Budapest,14-16, Budapest.

Runnels, D.D., 1969: Diagenesis, chemical sediments and the mixing of natural waters.- J. Sed. Petr., 39, 1188-1201.

Schafarzik, F. \& A. Vendl, 1929: Geological excursions in the environs of Budapest.- Stádium Sajtóvállalat Rt., pp. 343, Budapest. 
Szanyi, Gy., Bada, G., Surányi, G., Leél-Őssy, Sz. \& Zs. Varga, 2009: Pleistocene uplift rate of the Buda Hills (Hungary), using uranium-series dating of cave rafts.- Földtani Közlöny, 139/4, 445-468.

Takácsné Bolner, K. \& S. Kraus, 1989: The results of research into caves of thermal water origin.- Karszt és Barlang, Special Issue, 31-38.
Turner, G.M., Rasson, J.L. \& C.V. Reeves, 2007: Observation and measurement techniques.- In: Kono, $\mathrm{M}$. (ed.) Geomagnetism. Treatise on Geophysics, 5, 93146.

Wein, Gy., 1977: Tectonics of the Buda Mts.- MÁFI, pp. 76., Budapest. 